\title{
Visual Observations of Mixing Quality in a Prototype Canyon Tank
}

by

N. M. Hassan

Westinghouse Savannah River Company

Savannah River Site

Aiken, South Carolina 29808

DOE Contract No. DE-AC09-89SR18035

This paper was prepared in connection with work done under the above contract number with the U.S.

Department of Energy. By acceptance of this paper, the publisher and/or recipient acknowledges the U. S. Government's right to retain a nonexclusive, royalty-free license in and to any copyright covering this paper, along with the right to reproduce and to authorize others to reproduce all or part of the copyrighted paper. 


\section{DISCLAMMER}

This report was prepared as an account of work sponsored by an agency of the United States Government. Neither the United States Government nor any agency thereof, nor any of their employees, makes any warranty, express or implied, or assumes any legal liability or responsibility for the accuracy, completeness, or usefulness of any information, apparatus, product, or process disclosed, or represents that its use would not infringe privately owned rights: Reference herein to any specific commercial product, process, or service by trade name, trademark, manufacturer, or otherwise does not necessarily constitute or imply its endorsement, recommendation, or favoring by the United States Government or any agency thereof. The views and opinions of authors expressed herein do not necessarily state or reflect those of the United States Government or any agency thereof.

This report has been reproduced directly from the best available copy.

Available to DOE and DOE contractors from the Office of Scientific and Technical Information, P.O. Box 62, Oak Ridge, TN 37831; prices available from (615) 576-8401.

Available to the public from the National Technical Information Service, U.S. Department of Commerce, 5285 Port Royal Road, Springfield, VA 22161. 


\section{DISCLAIMER}

Portions of this document may be illegible in electronic image products. Images are produced from the best available original document. 
Keywords: Mixing quality

Dispersed phase

Two-phase mixture

Immiscible liquids

Retention : Permanent

Classification: $\mathbf{U}$

Damee \& taweinat 3-7.45

Authorized Derivative Classifier

Visual Observations of Mixing Quality in a Prototype Canyon Tank (U)

N. M. Hassan

March 10, 1995

Westinghouse Savannah River Company

P. O. Box 616

Aiken, SC 29802 
Visual Observations of Mixing Quality in a Prototype Canyon Tank (U)

$$
\text { By }
$$

N. M. Hassan

Issued: March 10, 1995

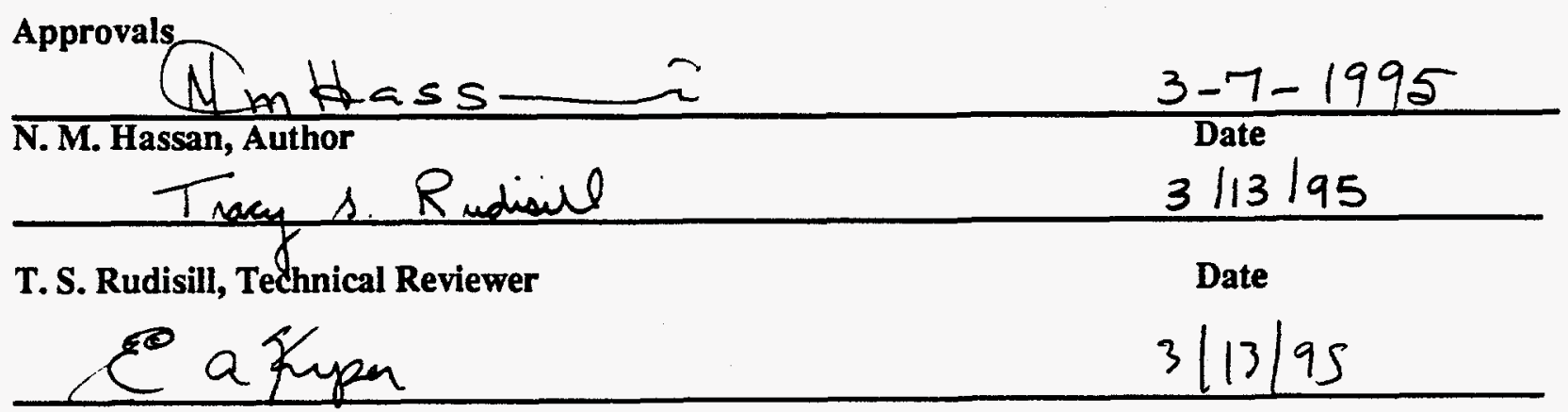

E. A. Kyser, Technical Reviewer 
Table of Contents

Section Page

Summary 1

Introduction 2

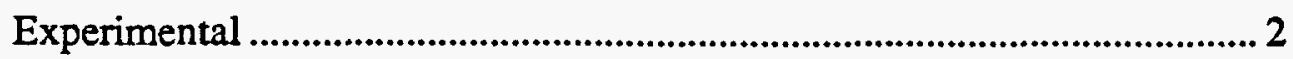

Materials and Apparatus ............................................................... 2

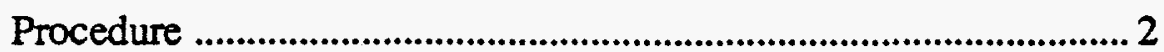

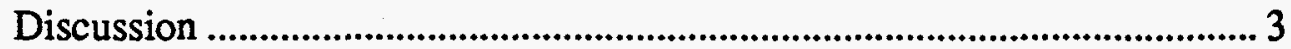

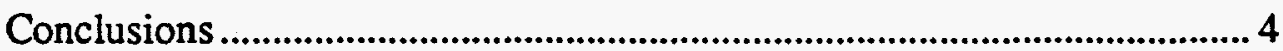

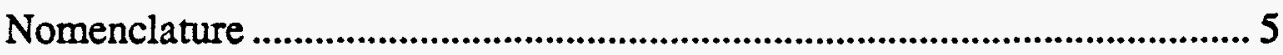

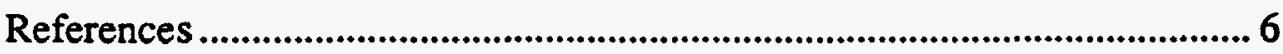

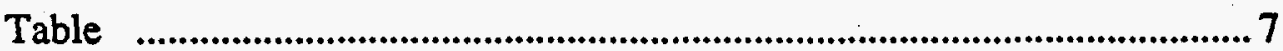

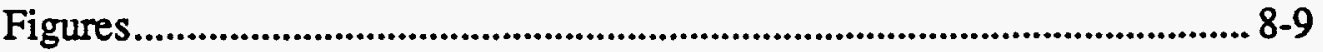




\section{SUMMARY}

A series of mixing tests were performed to identify the range of liquid levels and overall dispersed (organic) concentrations where a constant agitator speed representative of plant operations could eliminate a separate organic layer on the liquid surface. The test runs were made in a transparent, baffled, paddleagitated, Plexiglas ${ }^{\mathrm{TM}}$ vessel which was fitted with three concentric cooling coils. A visual observation method was used without taking any samples to determine the quality of mixing in the agitated vessel as a function of the total liquid level in the vessel at a given dispersed phase concentration ( 8 vol\%) and various organic phase concentrations at a constant water content. The observations have determined that gross uniform dispersion throughout a canyon tank can be achieved with the current plant impeller speed when the total liquid level is near the vicinity of the second (top) impeller. These observations were recorded in a video tape.

\section{INTRODUCTION}

A problem has arisen concerning the qualitative analysis of immiscible organic liquid in a predominantly aqueous phase in baffled mixing vessels (i.e. Plant tanks), resulting from significant variation in the concentration of such compounds at different locations in the vessel. The avoidance of explosive reactions in such vessels may depend upon immiscible organic accumulations not exceeding a certain low specified value. Confidence in the attainment of this goal was clearly dependent upon the quality of mixing prevailing under operating conditions. Clarification was therefore needed to provide a range of 
liquid levels where an organic phase would not be present on the liquid surface using overall organic concentrations greater than 8 vol\%.

\section{EXPERIMENTAL}

\section{Materials and Apparatus}

The materials used in this work were deionized water employed as the continuous phase and technical grade normal paraffin hydrocarbon supplied by Cole Chemical Company, Houston, Texas, as the dispersed (organic) phase. The normal paraffin was conservatively used instead of tributyl phosphate-nparaffin mixture (TBP/n-paraffin).

Figure 1 shows a schematic diagram of the experimental apparatus employed in this study. Briefly, it consisted of a cylindrical, flat-bottomed, Plexiglas ${ }^{\mathrm{TM}}$ tank, having an inside diameter $(\mathrm{T})$ of 18 inches and overall height (Z) of 36 inches. Six radial baffles of width equal to 1.25 inches were present in the tank to prevent vortex formation. Three concentric cooling coils made of 0.5 -inch diameter stainless steel tubing were mounted inside the baffles in the tank. The impellers used were two four-bladed flat-type turbines (paddles) mounted on a vertically centered shaft. The lower impeller in the flatbottomed vessel was located at an off-bottom clearance, $C$, of 1 inch; the spacing between the blades of the upper and lower impellers, S, was set at an interval of 9 inches. The shaft, impellers, and cooling coils were all made of 304 stainless steel. The small-scale laboratory set-up was a scaled down version of the 8 feet diameter $\times 11$ feet high plant tanks; a scale factor of 1:5.33 was used to maintain geometric similarity between large and small-scale units. Dimensions of the small-scale and plant size equipment are listed in Table 1.

Agitation was provided by a $1.8 \mathrm{HP}$ air motor with a maximum speed of $3000 \mathrm{rpm}$, supplied by Gast Manufacturing Corporation, Benton Harbor, Michigan. The air motor was connected to a 20-lb in-house compressed air line through a pressure regulator manufactured by ARO Corporation, Bryan, Ohio. The regulator was equipped with a pressure gauge and a filter. A lubricator was connected in the air line as close as practical to the air motor.

\section{Procedure}

There were a total of six test runs performed at various total liquid depths $(\mathrm{H})$ and dispersed (organic) phase concentrations. The predominant aqueous phase was first charged into the vessel and then the dispersed phase was introduced. The prototype tank wall was marked with a graduated scale to allow easy reading and control of the liquid levels to be introduced. Prior to each run the depth of the total liquid in the tank was adjusted to the desired level and the volume fractions of both phases were measured; the two-phase immiscible liquids formed two separate layers. A hand phototachometer was 
used to measure and control the impeller rotational speed at $270 \mathrm{rpm}$, which is representative of the plant operation. After agitation the volume fractions of the dispersed (organic) and aqueous phases were observed visually and video taped. In the first series of tests the water content in the tank was varied while holding the dispersed phase concentration constant at $8 \mathrm{vol} \%$. In the second set of tests the level of water in the tank was held constant and the dispersed phase concentration was increased from 8 to approximately 19 vol\%. liquid As a result, the depth of the total liquid in the tank increased from 15 to 17 inches.

This series of test runs was performed without using a Task or QA plan. However, important test controls were applied. First, the depth of the total liquid level and the percent volume of dispersed (organic) phase were carefully measured. The aqueous phase was first added into the tank and the level was carefully observed using a graduated scale on the transparent tank wall and a ruler. The level readings were taken by more than one observer in order to minimize possible observer's bias. Then a known volume of the dispersed (organic) phase was added into the tank and the depth of the total liquid was again carefully observed and adjusted if necessary. Thus a transparent, graduated tank, and careful obseravtion was sufficient and the procedure would have been no different had these tests been performed using a Task or QA plan.

Second, the phototachometer was calibrated using a standard manufacturer's calibration technique. The phototachometer is calibrated directly in rps using a fluorescent light bulb which provides a reading of 7200 . This recommended procedure would have been used had the test runs been performed under a Task or QA plan. Therefore, the procedure controls employed in this work are adequate and meet the QA requirements.

\section{DISCUSSION}

The dispersion of organic phase in an immiscible aqueous phase involves a number of distinctly different stages, each of which can be reasonably well defined (1-3). The stages of dispersion are identified with increasing rotational speed of impeller $(\mathrm{N})$ as shown schematically in Figure 2 . In this study, the agitator speed was held constant at $270 \mathrm{rpm}$, which is representative of the plant operation, and the quality of mixing in the tank was carefully observed as the depth of the total liquid in the tank and the overall dispersed phase concentration were varied. It was noted that when the depth of the total liquid in the tank was about 15 inches (i.e. the liquid level was approximately 6.7 feet in the plant scale), the operation was in stage 2 of the dispersion process. In this stage, the organic layer on the top of the aqueous surface started to disperse into the aqueous phase due to intense agitation in the immediate vicinity of the second impeller near the liquid surface. The dispersion of the 
organic in water expanded gradually to the middle of the tank through rather mild agitation. In the region below the interface, the two-phase mixture remained cloudy and the organic was partially dispersed for the duration of the mixing period. In the bottom half of the tank, the liquid was clear with little or no organic dispersion. However, a tremendous vertical motion of the liquid from the bottom of the tank was visually observed, particularly along the tank walls. As one can see in the video a top to bottom convective mixing action was prevailing in the tank due to discharge from radial flow generated by the paddle agitators.

At liquid levels below the top impeller (i.e. 10 inches total liquid), an organic layer approximately 1 inch thick remained on the top of the aqueous phase with relatively little motion. Similarly, the organic layer on top of the agitated aqueous phase was about 1 inch thick when the depth of total liquid was 17 inches at the 8 vol\% organic. In both cases a wave-like motion of the organic layer was observed although the shearing influence of the low-speed impeller ( $s$ ) was insufficient to induce gross uniform dispersion. Thus a grossly uniform dispersion of the organic layer into the agitated aqueous phase was observed only at a total liquid depth of 15 inches in the small scale unit., which corresponds to a total liquid depth of about 7 feet for the geometrically similar plant scale unit operating at the current plant impeller speed.

The effects of the overall dispersed phase concentration on the quality of mixing was visually examined. At 14 vol\% organic and 16 inches total liquid depth in the small-scale unit, the impellers produced gross uniform dispersion throughout the vessel. By increasing the organic phase concentration to 19 vol\% with corresponding increase in the total liquid depth to 17 inches, an incomplete partial dispersion was produced by the mild agitation and the quality of mixing at that point was not good as suggested by the thin organic layer (about $1 / 2$ inch thick) at the top of the liquid surface. This layer was in a constant state of motion in a wave-like form and periodically its thickness was reduced to less than $1 / 2$ inch. Thus the observation made suggest that the effects of the overall concentration of the organic phase are slight and the mixing quality improves slightly as the overall concentration of the dispersed phase decreases.

\section{CONCLUSIONS}

Visual observation of the quality of mixing in a small-scale unit with representative materials and agitator speed in a geometrically scaled-down version of Separations process tanks failed to detect an acceptable range of liquid levels where the agitation is sufficient to disperse greater than 8 vol\% organic. The abservations, however, determined that gross uniform dispersion can be achieved when the total liquid level is in the immediate vicinity of the second (top) impeller. As the total liquid depth and the percent volume of 
organic were increased, an incomplete partial dispersion was visually observed throughout the tank. Nevertheless a strong upward flow of the bulk aqueous phase was clearly visible along the tank wall. This upward convective flow was apparently produced as a result of a high degree of turbulence ( $\operatorname{Re}=58,760$ ) in the agitated tank.

The observations also determined visually that an organic layer about $1 / 2$ inch thick, which corresponds to a thickness of approximately 3 inches in a canyon tank, remained on the top of the tank when the ratio of the total liquid to the tank diameter was approximately 1 and the overall organic concentration was about 19 vol\%. This layer was in a constant wave-like motion and periodically its thickness was reduced to less than $1 / 2$ inch. Below the second (top) impeller, the organic layer was about 1 inch thick (i.e. 5 inch thick in a canyon tank) when the overall organic concentration was 8 vol\%. The layer was clearly visible on the top of the aqueous phase and was constantly in wave-like motion. Thus the observations suggest that the effects of the overall dispersed (organic) phase concentration on the mixing quality are slight. 


\section{NOMENCLATURE}

$\begin{array}{ll}\text { B } & \text { baffle width } \\ \mathrm{C} & \text { impeller clearance from tank bottom } \\ \mathrm{D} & \text { impeller blade diameter } \\ \mathrm{d} & \text { shaft diameter } \\ \mathrm{d}_{\mathrm{C}} & \text { diameter of the coils } \\ \mathrm{H} & \text { total height of liquid in the tank } \\ \mathrm{h} & \text { vertical height of sampling point above tank floor } \\ \mathrm{L} & \text { shaft length } \\ \mathrm{N} & \text { impeller rotational speed } \\ \mathrm{p} & \text { distance between two corresponding points on the coils } \\ \mathrm{r}_{\mathrm{O}} & \text { radial location outside the coils } \\ \mathrm{rb}_{\mathrm{b}} & \text { radial location between the coils } \\ \mathrm{S} & \text { distance between impellers } \\ \mathrm{T} & \text { tank diameter } \\ \mathrm{t} & \text { impeller blade thickness } \\ \mathrm{w} & \text { impeller blade width } \\ \mathrm{Z} & \text { tank height }\end{array}$




\section{REFERENCES}

1. N. M. Hassan "Mixing Quality Characterization in Separation's Process Tanks (U)", WSRC-TR-95-0028, Westinghouse savannah River Company, January 1995

2. A. H. P. Skelland and G. G. Ramsay, "Minimum Impeller Speeds for Complete Liquid-Liquid Dispersion, Ind. Eng. Chem. Res 26, 77 (1987).

3. A. H. P. Skelland and R. Seksaria, "Minimum Impeller Speeds for LiquidLiquid Dispersion in Baffled Vessels, Ind. Eng. Chem. Process Des. and Dev. 17, 56 (1978). 
Table 1. Dimensions of Lab Scale and Plant Scale Units*

\begin{tabular}{|c|c|c|c|}
\hline Unit & lab-scale tank & $\begin{array}{l}\text { plant-scale } \\
\text { tank }\end{array}$ & Remarks \\
\hline $\begin{array}{l}\text { T a n } \mathbf{k} \\
\begin{array}{l}\text { diameter, } T \\
\text { height, } Z\end{array}\end{array}$ & $\begin{array}{l}18 \\
36\end{array}$ & $\begin{array}{c}96 \\
121\end{array}$ & $\begin{array}{l}\text { plant scale tanks- } \\
8 \times 11 \text { feet vessels }\end{array}$ \\
\hline $\begin{array}{l}\text { I m p e l I e r } \\
\text { diameter, } D \\
\text { width, w } \\
\text { thickness, } t \\
\text { \# of blades }\end{array}$ & $\begin{array}{l}4.5 \\
1.0 \\
0.125 \\
4 \\
\end{array}$ & $\begin{array}{c}24 \\
5 \\
0.75 \\
4\end{array}$ & $\begin{array}{l}\text { off scale by } 0.0625 \\
\text { off scale by } 0.0156\end{array}$ \\
\hline $\begin{array}{l}\text { Sh a f t } \\
\text { diameter, d } \\
\text { length, } L\end{array}$ & $\begin{array}{c}0.625 \\
42\end{array}$ & $\begin{array}{c}3.375 \\
226\end{array}$ & \\
\hline $\begin{array}{c}\text { B affles } \\
\text { width, B } \\
\# \text { of baffles } \\
\end{array}$ & $\begin{array}{c}1.25 \\
6 \\
\end{array}$ & $\begin{array}{l}7 \\
6 \\
\end{array}$ & $\begin{array}{c}\text { width off-scale by } \\
0.0625 \\
\end{array}$ \\
\hline $\begin{array}{l}\text { Cooling coils } \\
\text { Inner coils } \\
\text { diameter, } d_{c} \\
\text { pitch, } p \\
\text { Middle coils } \\
\text { diameter, } d_{c} \\
\text { pitch, } p \\
\text { Outer coils } \\
\text { diameter, } d_{c} \\
\text { pitch, } p\end{array}$ & $\begin{array}{c}8 \\
0.68 \\
\\
10.6 \\
0.8 \\
\\
13.3 \\
1.0\end{array}$ & $\begin{array}{c}45 \\
3.625 \\
\\
60 \\
4.25 \\
\\
75 \\
5.375\end{array}$ & $\begin{array}{l}7 \text { turns } \\
11 \text { turns } \\
12 \text { turns }\end{array}$ \\
\hline $\begin{array}{l}\text { Off bottom } \\
\text { clearance, } \mathrm{C} \\
\text { Distance between } \\
\text { impellers, } \mathrm{S}\end{array}$ & 1 & 6 & \\
\hline
\end{tabular}

* all dimensions are in inches 


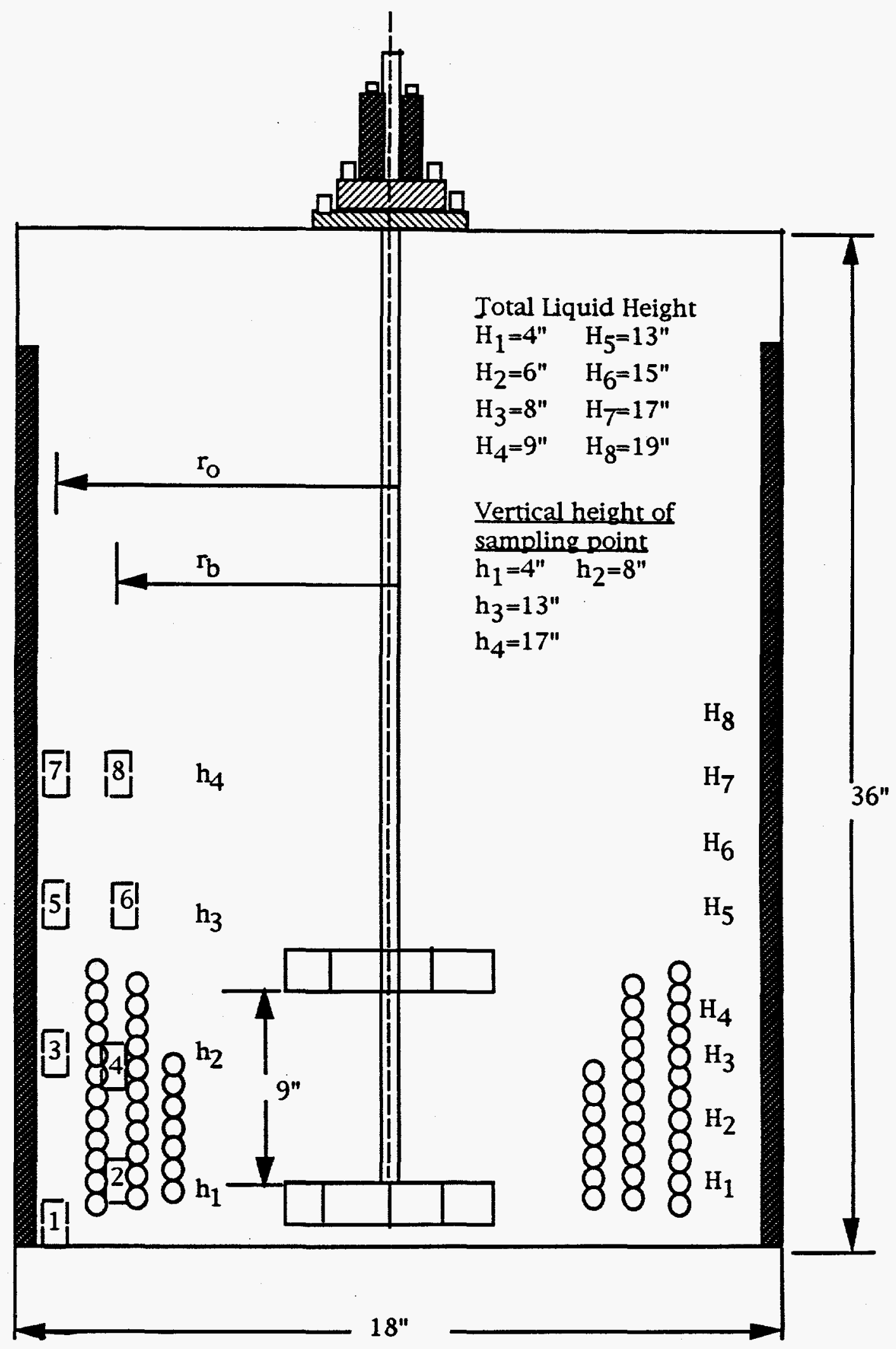

Figure 1. Schematic diagram of the experimental apparatus 
Chemical Process Technology Department

Chemical \& Hydrogen Technology Section

WSRC-TR-95-0108

Revision 0

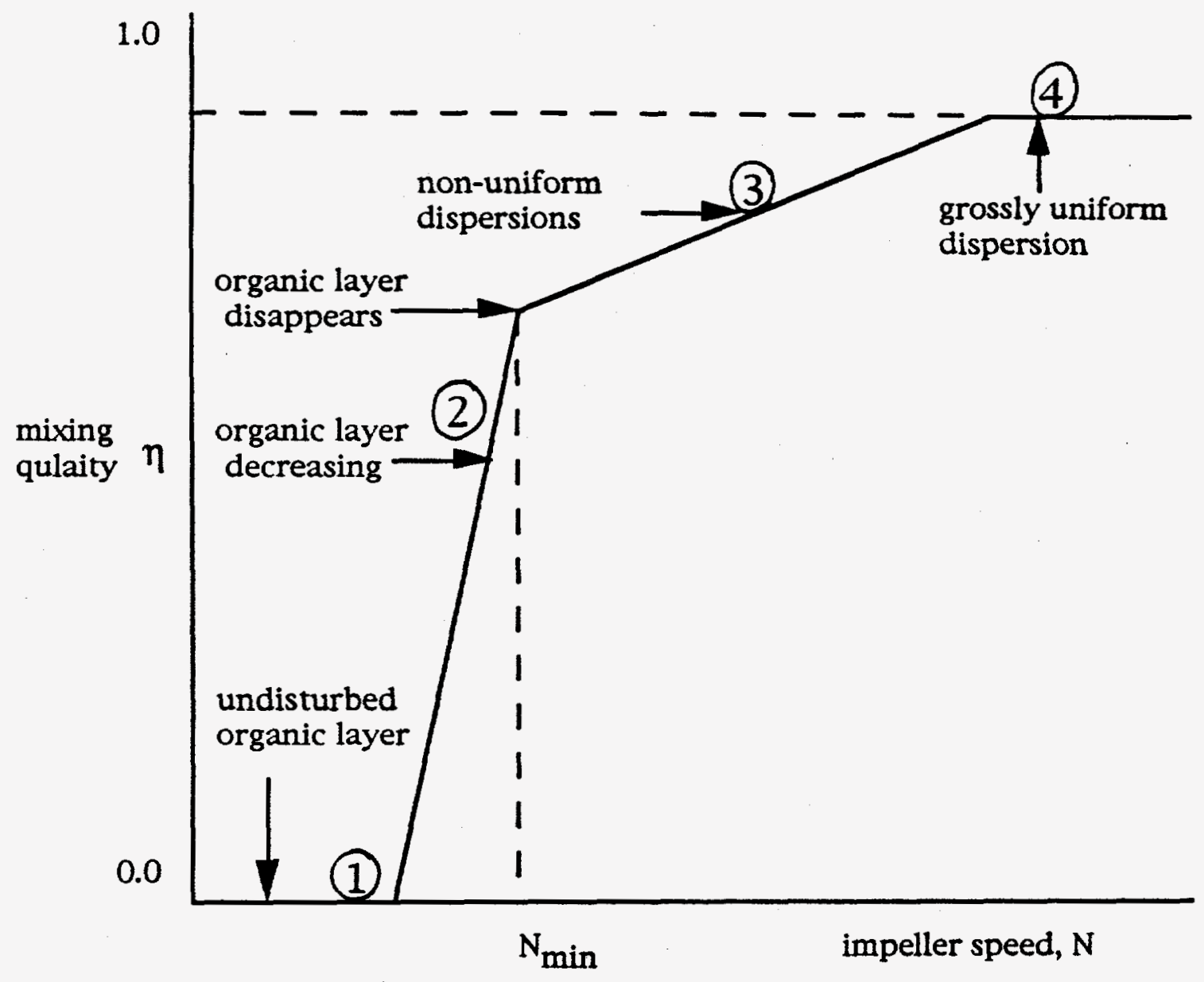

Figure 2. A schematic diagram of the effect of impeller speed on stages of dispersion in immiscible liquid-liquid systems. 


\section{WSRC DISTRIBUTION}
A. P. Gouge, 703-F
C. B. Cochran, 703-F
C. E. Pickett, 221-H
C. R. Wolfe, 773-A
D. F. Chostner, 703-F
E. A. Kyser, 773-A
F. R. Graham, 773-A
J. R. Knight, 773-A
J. R. Schornhorst, 992W-1
J. S. Evans, 703-F
M. C. Thompson, 773-A
M. L. Hyder, 773-A
O. M. Ebralima, 703-F
R. L. Eubanks, 221-F
T. G. Campbell, 707-F
T. S. Rudisill, 773-A
STI, 703-43A 